\title{
Knockdown of Hotair suppresses proliferation and cell cycle progression in hepatocellular carcinoma cell by downregulating CCND1 expression
}

\author{
JIA-JIA ZHOU ${ }^{1 *}$, DI CHENG $^{1 *}$, XIAO-YU HE ${ }^{2}$, ZHE MENG $^{1}$, WEN-ZHU LI $^{1}$ and RU-FU CHEN ${ }^{1}$ \\ ${ }^{1}$ Guangdong Provincial Key Laboratory of Malignant Tumor Epigenetics and Gene Regulation, Sun Yat-sen \\ Memorial Hospital, Sun Yat-sen University, Guangzhou, Guangdong 510120; ${ }^{2}$ Laboratory of Biomechanics and Physiology, \\ Guangdong Provincial Institute of Sports Science, Guangzhou, Guangdong 510663, P.R. China
}

Received October 24, 2016; Accepted June 14, 2017

DOI: $10.3892 / \mathrm{mmr} .2017 .7162$

\begin{abstract}
The long noncoding RNA, homeobox transcript antisense RNA (Hotair), has been demonstrated to have an important role in regulating various biological processes in various cancers, including hepatocellular carcinoma (HCC). However, the importance of Hotair in HCC proliferation and cell cycle progression remains to be elucidated. In the present study, knockdown of HOTAIR expression by RNA interference inhibited cell proliferation and induced G0/G1 cell cycle arrest in Huh7 hepatocellular carcinoma cells. In addition, the expression levels of CCND1 mRNA and its cyclin D1 protein product were reduced in Huh7 cells following knockdown of HOTAIR. Knockdown of HOTAIR reduced the expression of phosphorylated signal transducer and activator of transcription 3 (STAT3) and HOTAIR knockdown combined with STAT3 inhibition led to an additional decrease in cyclin D1 expression. The present study suggested that Hotair may have a critical role in the proliferation of $\mathrm{HCC}$ by regulating cell cycle, STAT3 activity and cyclin D1 expression. Therefore, Hotair may be a novel potential therapeutic target for HCC treatment.
\end{abstract}

\section{Introduction}

Hepatocellular carcinoma (HCC) is currently one of the most common malignant tumors worldwide and the morbidity and

Correspondence to: Dr Jia-Jia Zhou, Guangdong Provincial Key Laboratory of Malignant Tumor Epigenetics and Gene Regulation, Sun Yat-sen Memorial Hospital, Sun Yat-sen University, 107 West Yan Jiang Road, Guangzhou, Guangdong 510120, P.R. China

E-mail: jiajiazh2004@126.com

*Contributed equally

Key words: hepatocellular carcinoma, homeobox transcript antisense RNA, proliferation, cell cycle, CCND1 gene, signal transducer and activator of transcription 3 mortality associated with HCC are high, which may be in part due to late diagnosis, by which time cancer progression is quite advanced (1). Previous studies have demonstrated that long noncoding RNAs (lncRNAs) have an important role in the regulation of various biological processes in cancers, including proliferation, metastasis, cancer progression and epithelial-to-mesenchymal transition $(2,3)$. Therefore, investigation of the roles of lncRNAs in carcinogenesis and the progression of HCC is required.

Human lncRNA, homeobox transcript antisense intergenic RNA (Hotair), a 2.2 kb RNA transcribed from the Hoxc locus, interacts with both polycomb repressive complex (PRC2) and lysine-specific histone demethylase 1A complexes to enhance histone $\mathrm{H} 3$ lysine trimethylation and histone $\mathrm{H} 3$ lysine 4 demethylation, leading to the silencing of multiple genes $(3,4)$. A previous study determined that Hotair was upregulated in breast cancer and associated with cancer invasiveness and metastasis (3). Subsequent studies revealed that Hotair promotes proliferation and reduces apoptosis in pancreatic cancer, colorectal cancer and glioma cells (5-7). In addition, it has been reported that Hotair was overexpressed in $\mathrm{HCC}$ and this was positively associated with poor prognosis, tumor progression and recurrence of HCC, suggesting that Hotair functions as an oncogene $(8,9)$. However, the potential role of Hotair in regulating cell proliferation and cell cycle progression in HCC and the underlying molecular mechanism remain to be fully elucidated.

Cell proliferation is associated with cell cycle progression. Cell cycle is divided into G0/G1, S and G2/M phases, which are controlled by various cyclin-dependent kinases (CDKs) $(10,11)$. The critical regulation point of the cell cycle is the $\mathrm{G} 1$ checkpoint. Cyclin D1 (encoded by the CCNDI gene), is a $\mathrm{G} 1$ cyclin and is an important for regulating the transition of G1 to S (G1-S) in different cell types (11). By cooperating with its binding partners CDK4 and CDK6, cyclin D1 promoted the phosphorylation of retinoblastoma protein, leading to the activation of E2F transcription factors; therefore, enabling cell cycle progression through $\mathrm{G} 1$ into the $\mathrm{S}$ phase (11). CCNDI overexpression is commonly observed in various types of human cancers, including HCC, and serves a critical role in the initiation of carcinogenesis (12). CCNDl is also involved 
in abnormal cell growth processes, angiogenesis and resistance to apoptosis, making it a potential therapeutic target for controlling tumor growth $(13,14)$. However, the association of Hotair and CCNDI expression in HCC remains unclear.

In the present study, the potential role of Hotair in regulating proliferation and $C C N D 1$ expression in the Huh7 $\mathrm{HCC}$ cell line was investigated. Knockdown of HOTAIR inhibited cell proliferation and blocked the cell cycle at the G0/G1 checkpoint by reducing CCND1 and cyclin D1 expression and this effect was enhanced by the inhibition of signal transducer and activator of transcription 3 (STAT3). These findings may provide an insight into the underlying mechanism of Hotair in regulating cell proliferation and cell cycle progression of HCC and suggest that Hotair may be a potential therapeutic target for HCC treatment.

\section{Materials and methods}

Cell line and culture. The human Huh7 hepatocellular carcinoma cell line was purchased from the American Type Culture Collection (Manassas, VA, USA). Cells were maintained in Dulbecco's modified Eagle's medium supplemented with $10 \%$ fetal bovine serum (Hyclone; GE Healthcare, Logan, UT, USA) at $37^{\circ} \mathrm{C}$ in an atmosphere of $5 \% \mathrm{CO}_{2}$ with humidity. The culture medium was changed every $24 \mathrm{~h}$. Cells were treated with $50 \mu \mathrm{M}$ AG490 (Sigma-Aldrich; Merck KGaA, Darmstadt, Germany) and incubated in a humidified chamber supplemented with $5 \% \mathrm{CO}_{2}$ at $37^{\circ} \mathrm{C}$ for $48 \mathrm{~h}$.

Hotair siRNA transfection. Knockdown of human HOTAIR (Gene ID, 100124700) was achieved by transfection of small interfering RNA (siRNA). The siRNA sequences were as follows: HOTAIR, 5'- UAACAAGACCAGAGAGCUGUU -3 and negative control (NC), 5'-TTCTCCGAACGTGTCACG T-3'. The sequences of siRNA were previously described $(8,15)$ and were synthesized by Shanghai GenePharma Co., Ltd. (Shanghai, China). Cells were seeded in 24-well culture dishes at a density of $10^{5}$ cells/well and incubated in a humidified chamber supplemented with $5 \% \mathrm{CO}_{2}$ at $37^{\circ} \mathrm{C}$. siRNA $(2 \mu \mathrm{M})$ transfection was performed using Lipofectamine ${ }^{\mathrm{TM}} 3000$ $(1 \mu \mathrm{M})$ (Invitrogen; Thermo Fisher Scientific, Inc., Waltham, MA, USA) for $25 \mathrm{~min}$ at room temperature according to the manufacturer's protocol. After transfection, cells were incubated in a humidified chamber supplemented with $5 \% \mathrm{CO}_{2}$ at $37^{\circ} \mathrm{C}$ for $48 \mathrm{~h}$. Mock-transfected cells were transfected with Lipofectamine $^{\text {TM }} 3000$ without siRNA.

Reverse transcription-quantitative polymerase chain reaction (RT-qPCR). RT-qPCR was performed to determine the expression levels of IncRNA HOTAIR and the mRNA expression of CCND1. Briefly, $24 \mathrm{~h}$ after transfection, total RNA of the cells was harvested using RNAiso Plus reagent (Takara Biotechnology Co., Ltd., Dalian, China). Total RNA was reverse transcribed into cDNA using PrimeScript ${ }^{\mathrm{TM}}$ RT Reagent kit with gDNA Eraser (Takara Biotechnology Co., Ltd.). Thermocycling conditions were as follows: At $37^{\circ} \mathrm{C}$ for $15 \mathrm{~min}$, at $85^{\circ} \mathrm{C}$ for $5 \mathrm{sec}$ to inactivate the enzyme, and cooling at $37^{\circ} \mathrm{C}$ for $1 \mathrm{~min}$. qPCR was performed on cDNA using SYBR ${ }^{\circledR}$ Premix Ex Taq ${ }^{\mathrm{TM}}$ II (Takara Biotechnology Co., Ltd.). The reaction volume was $25 \mu 1$, containing SBYR
Premix Ex Taq II (12.5 $\mu 1), 1 \mu \mathrm{l}$ of each forward and reverse primer, cDNA $(2 \mu \mathrm{l})$ and $\mathrm{dH}_{2} \mathrm{O}(8.5 \mu \mathrm{l})$. Thermocycling conditions were as follows: Initial denaturation at $95^{\circ} \mathrm{C}$ for 5 min, followed by 40 cycles of denaturation at $95^{\circ} \mathrm{C}$ for $20 \mathrm{sec}$, annealing at $58^{\circ} \mathrm{C}$ for $30 \mathrm{sec}$ and elongation at $72^{\circ} \mathrm{C}$ for $30 \mathrm{sec}$. The relative expression levels of $C C N D 1 \mathrm{mRNA}$ and lncRNA HOTAIR were calculated according to the comparative $\mathrm{Cq}$ method and normalized to GAPDH expression (16). The following primers were used in the present study: HOTAIR, forward 5'-CAGTGGGGAACTCTGACT CG-3', reverse 5'-GTGCCTGGTGCTCTCTTACC-3'; CCND1, forward 5'-CCGCCTCACACGCTTCCTCTC-3', reverse 5'-CGGCCTTGGGGTCCATGTTCT-3'; GAPDH, forward 5'-GCACCGTCAAGGCTGAGAAC-3', reverse 5'-TGGTGA AGACGCCAGTGGA-3'.

Western blotting. After $48 \mathrm{~h}$ transfection, the cells were lysed with radioimmunoprecipitation assay lysis buffer (Cell Signaling Technology, Inc., Danvers, MA, USA) in the presence of protease/phosphatase inhibitor cocktail (Cell Signaling Technology, Inc.) at $4^{\circ} \mathrm{C}$ for $30 \mathrm{~min}$, and the lysates were centrifuged at $12,000 \mathrm{x} \mathrm{g}$ at $4^{\circ} \mathrm{C}$ for $20 \mathrm{~min}$. The concentration of protein was measured using a bicinchoninic acid protein assay kit (Thermo Fisher Scientific, Inc.). Equal amounts $(30 \mu \mathrm{g})$ of extracted protein samples were separated by $10 \%$ SDS-PAGE and transferred onto polyvinylidene difluoride membranes (EMD Millipore, Billerica, MA, USA). After blocking with 5\% non-fat milk for $2 \mathrm{~h}$ at room temperature, the membranes were incubated with the following primary antibodies at $4^{\circ} \mathrm{C}$ under gentle agitation overnight: Rabbit monoclonal cyclin D1 antibody (1:10,000; cat no. ab134175; Abcam, Cambridge, UK), rabbit polyclonal phosphorylated (p)-STAT3 (Tyr705) antibody (1:2,000; cat no. 9145; Cell Signaling Technology, Inc.), mouse monoclonal STAT3 antibody (1:1,000; cat no. 9139; Cell Signaling Technology, Inc.) and mouse monoclonal GAPDH antibody (1:1,000; cat no. sc-47724; Santa Cruz Biotechnology, Inc., Dallas, TX, USA). Subsequently, membranes were incubated with horseradish peroxidase-conjugated goat anti-rabbit (cat no. SA00001-2) or goat anti-mouse (cat no. SA00001-1) antibodies (1:5,000; ProteinTech Group, Inc., Chicago, IL, USA) for $2 \mathrm{~h}$ at room temperature under gentle agitation. Protein bands were visualized using the Supersignal ${ }^{\circledR}$ West Pico Chemiluminescent substrate (Thermo Fisher Scientific, Inc.) on X-ray films. Blots were semi-quantified by densitometric analysis using Image J software version 1.51 (National Institutes of Health, Bethesda, MD, USA).

Cell proliferation assay. Cell proliferation assay was performed using a Cell Counting Kit-8 (CCK-8; Dojindo Molecular Technologies, Inc., Kumamoto, Japan) assay. Cells were seeded in 96-well plates (Corning Inc., Corning, NY, USA) at a density of $10^{4}$ cells/well and incubated in a humidified chamber supplemented with $5 \% \mathrm{CO}_{2}$ at $37^{\circ} \mathrm{C}$. The $\mathrm{CCK}-8$ assay was used to detect the viability of cells following the manufacturer's protocol. CCK-8 solution (10 $\mu \mathrm{l})$ was added in each well and cells were incubated in a humidified chamber supplemented with $5 \% \mathrm{CO}_{2}$ at $37^{\circ} \mathrm{C}$ for $1 \mathrm{~h}$. The absorbance was measured at a wavelength of $450 \mathrm{~nm}$ using a microplate reader. Six replicate wells were used for each group. 
A

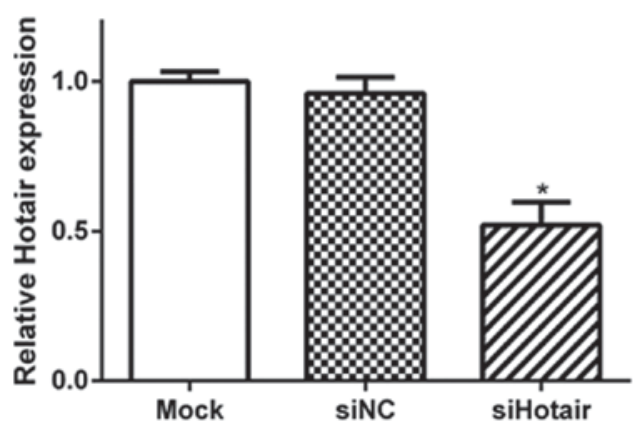

B

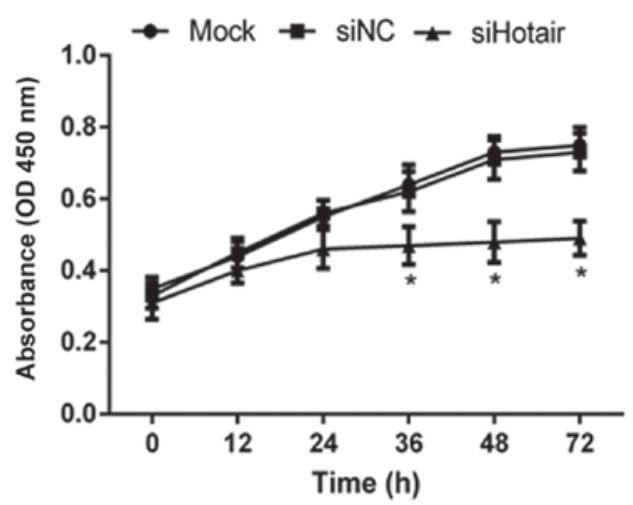

Figure 1. Knockdown of HOTAIR inhibits Huh7 cell proliferation. (A) mRNA expression levels of HOTAIR in Huh7 cells transfected with siHotair, siNC, or Mock transfected with Lipofectamine alone, were detected by reverse transcription-quantitative polymerase chain reaction. (B) Cell proliferation of Huh7 cells in each group was measured by a Cell Counting kit- 8 assay. Data are presented as mean \pm standard deviation of three independent experiments. ${ }^{*} \mathrm{P}<0.05$ vs. siNC. HOTAIR, homeobox transcript antisense RNA gene; siHotair, small interfering RNA targeting HOTAIR; siNC, small interfering RNA targeting negative control.

Cell cycle analysis. The cell cycle profile was analyzed using flow cytometry. Briefly, $1 \times 10^{6}$ cells were harvested and fixed with ice-cold $75 \%$ ethanol at $4{ }^{\circ} \mathrm{C}$ overnight and incubated with propidium iodide (PI; $50 \mu \mathrm{g} / \mathrm{ml}$; Sigma-Aldrich, Merck $\mathrm{KGaA}$ ) in the dark at room temperature for $30 \mathrm{~min}$. Flow cytometric analysis was performed on a Beckman Coulter EPICS analyzer (Beckman Coulter, Inc., Brea, CA, USA). Multicycle AV software version 3.0 (Phoenix Flow Systems, San Diego, CA, USA) was employed for calculating the cell cycle phase distribution from the resultant DNA histogram.

Statistical analysis. Data are presented as mean \pm standard deviation of 3 independent experiments. Statistical analysis was performed using using SPSS software version 13.0 (SPSS, Inc., Chicago, IL, USA). The statistical significance of the differences between groups was assessed using a two-tailed Student's t-test or one-way analysis of variance followed by a Tukey post hoc test. $\mathrm{P}<0.05$ was considered to indicate a statistically significant difference.

\section{Results}

Knockdown of HOTAIR by specific siRNA. In order to investigate the potential role of Hotair in HCC, specific siRNA targeting HOTAIR was used to transfect Huh7 hepatocarcima cells to silence HOTAIR expression. Transfection of Huh7 cells with HOTAIR siRNA resulted in significant knockdown of HOTAIR expression compared with the siNC group $(\mathrm{P}<0.05$; Fig. 1A). NC siRNA had no significant impact on the expression level of HOTAIR compared with the Mock cells.

Knockdown of HOTAIR inhibits proliferation of Huh7 cells. The role of Hotair on the prolferation of Huh7 cells, was examined by determining the effect of HOTAIR siRNA on cell growth. The proliferation of HOTAIR knockdown cells was significantly reduced compared with the siNC and Mock cells at 36, 48 and $72 \mathrm{~h}$ post-transfection $(\mathrm{P}<0.05$; Fig. 1B).

Knockdown of HOTAIR arrests the cell cycle of Huh7 cells. To evaluate whether Hotair has a role in the regulation of cell cycle progression of Huh7 cells, the cell cycle phases of HOTAIR knockdown cells were analyzed. The present study determined that the cell cycle was primarily blocked at the G0/G1 checkpoint in the HOTAIR knock-down cells, compared with the NC and Mock cells. In the HOTAIR knockdown cells, the $\mathrm{G} 0 / \mathrm{G} 1$ ratio was significantly higher and the proportion of cells in $\mathrm{S}+\mathrm{G} 2 / \mathrm{M}$ was significantly lower than the $\mathrm{NC}$ and Mock cells $(\mathrm{P}<0.05$; Fig. 2$)$.

Knockdown of HOTAIR decreases expression of CCND1 in Huh7 cells. To evaluate the role of Hotair on the proliferation and cell cycle of Huh7 cells, the expression level of a key regulator of the G1-S phase transition, $C C N D 1$, was measured. CCND1 expression was positively associated with HOTAIR expression in Huh7 cells. Compared with the siNC group, the mRNA expression levels of CCND1 (Fig. 3A) and its cyclin D1 protein product (Fig. 3B and $\mathrm{C}$ ) were significantly reduced in HOTAIR knockdown cells $(\mathrm{P}<0.05)$.

Knockdown of HOTAIR inhibits expression of pSTAT3 in Huh7 cells. As cyclin D1 has been demonstrated to be a downstream target of STAT3, the present study investigated whether Hotair regulated cyclin D1 expression via the STAT3 signaling pathway. Compared with the siNC group, the protein expression levels of cyclin D1 and phosphorylated (p) STAT3 were significantly reduced in HOTAIR knockdown cells $(\mathrm{P}<0.05$; Fig. 4). However, the expression level of total STAT3 was not affected in the HOTAIR knockdown cells, compared with the siNC group.

Knockdown of HOTAIR combined with STAT3 inhibition leads to an additional decrease in CCND1 expression. To further explore the effect of Hotair and STAT3 signaling on cyclin D1 expression. Huh7 cells were treated with the STAT3 inhibitor, AG490, for $1 \mathrm{~h}$ prior to HOTAIR siRNA transfection. Cyclin D1 and pSTAT3 expression levels were suppressed following AG490 treatment in cells transfected with or without siHotair; however, the suppresion was greater in the cells treated with AG490 and HOTAIR siRNA in combination $(\mathrm{P}<0.05$, Fig. 5). Overall, the data suggested that reduced HOTAIR expression 

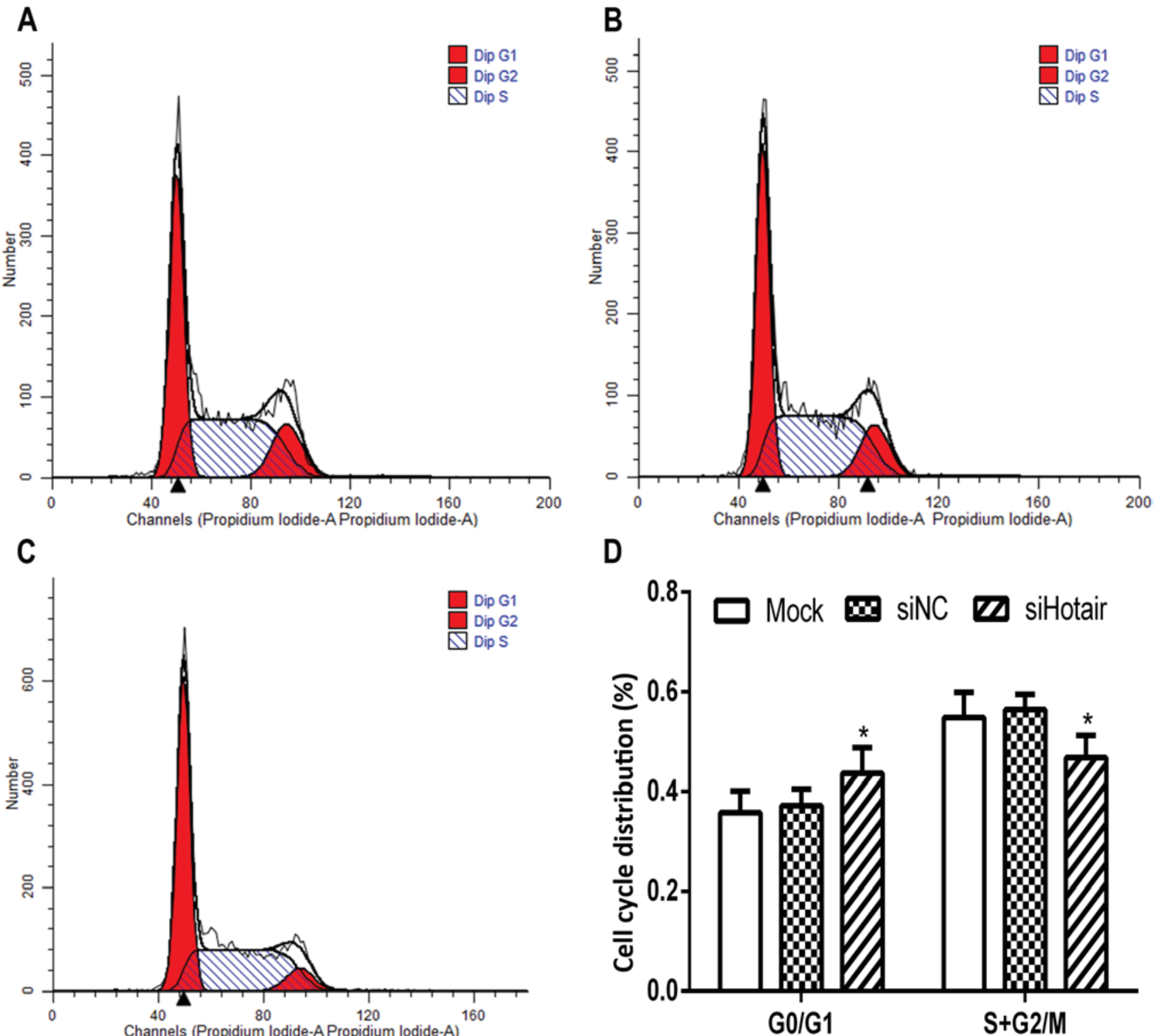

D

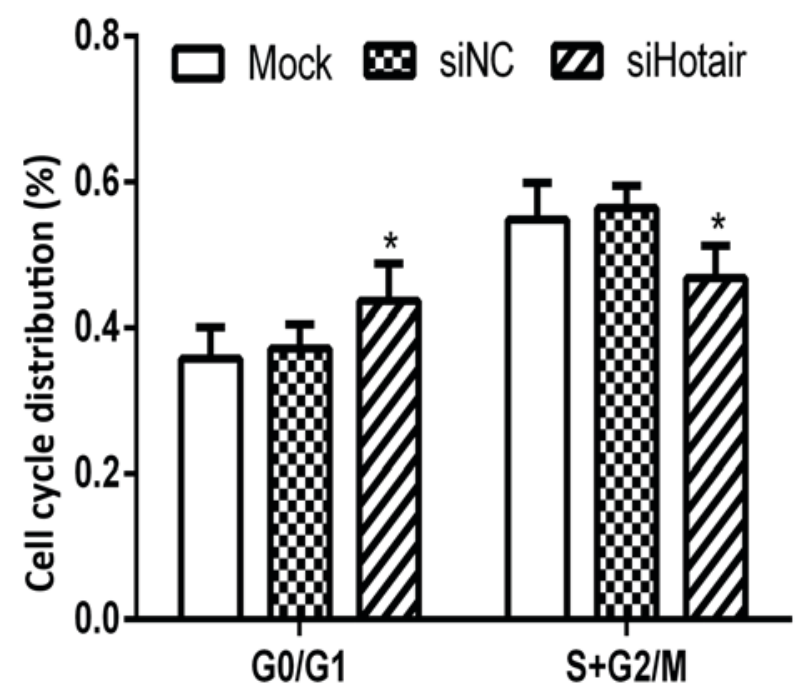

Figure 2. Knockdown of HOTAIR arrests cell cycle of Huh7 cells. Cell cycle analysis of Huh7 cells transfected with (A) Lipofectamine alone (Mock), (B) siNC or (C) siHotair. (D) Cell cycle distribution of Huh7 cells in each group was compared. Data are presented as mean \pm standard deviation of three independent experiments. "P<0.05 vs. siNC. HOTAIR, homeobox transcript antisense RNA gene; siHotair, small interfering RNA targeting HOTAIR; siNC, small interfering RNA targeting negative control.

was associated with reduced cyclin D1 expression and STAT3 phosphorylation. Knockdown of HOTAIR combined with STAT3 inhibition led to an additional decrease in cyclin D1 expression and STAT3 phosphorylation compared with individual treatments.

\section{Discussion}

The G1/S phase transition in the cell cycle is crucial for unlimited cell proliferation and tumor growth. A previous study revealed that several lncRNAs appear to be correlated with aberrant proliferation of cancer cells (17). In the present study, knockdown of lncRNA HOTAIR suppressed cell proliferation and inhibited G1/S phase transition of cell cycle.

Unlimited proliferation is a feature of cancer and is associated with aberrant cell cycle progression $(18,19)$. Dysregulation of the G1/S phase transition may lead to unlimited cell proliferation $(11,12)$. A previous study revealed that Hotair was overexpressed in HCC specimens, and in HepG2 and Huh7 cell lines (8). In the present study, knockdown of HOTAIR led to the inhibition of cell proliferation of Huh7 cells. Furthermore, flow cytometric analysis demonstrated that knockdown of HOTAIR increased the percentage of cells in the G0/G1 phase and reduced the percentage of Huh7 cells in the $S+G 2 / M$ phase. These findings suggested that Hotair may be a novel regulator of the G1/S phase transition and cell proliferation in HCC cells. Cyclin D1 protein (encoded by the CCND1 gene) is considered to be a critical regulator in G1-S phase transition, and cyclin D1 and Hotair were overexpressed in $\operatorname{HCC}(8,12)$. Therefore, the present study investigated the effect of Hotair on CCNDI and cyclin D1 expression. Indeed, knockdown of HOTAIR resulted in a reduction in the $C C N D 1$ protein and mRNA expression levels, suggesting that Hotair is an upstream regulator of cyclin D1 expression. Collectively, this data may shed light on the 

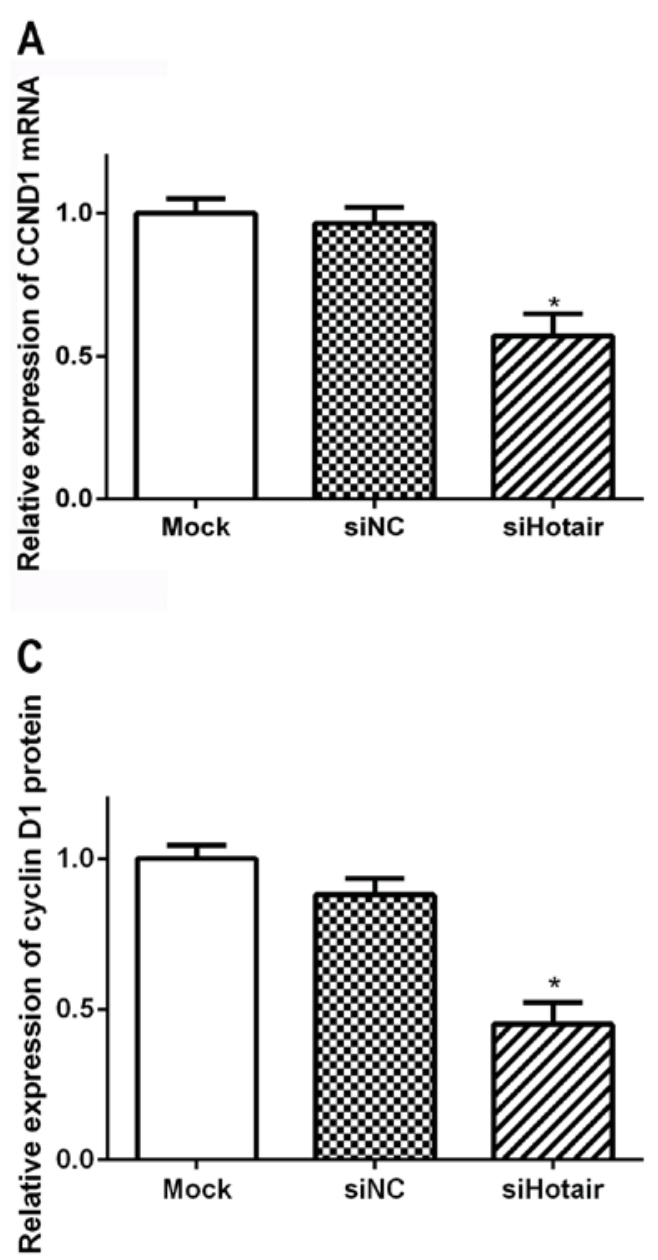

B

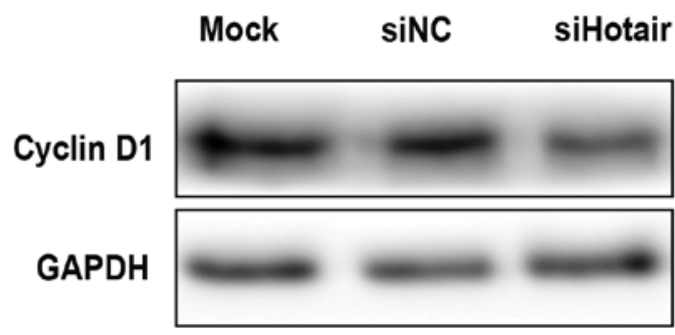

Figure 3. Knockdown of HOTAIR decreases expression levels of CCND1 and cyclin D1 in Huh7 cells. Huh7 cells were transfected with Lipofectamine alone (Mock), siHotair or siNC and (A) mRNA expression levels of CCND1 and (B and C) cyclin D1 protein expression levels were measured. Data are presented as mean \pm standard deviation of three independent experiments. " $\mathrm{P}<0.05$ vs. siNC. HOTAIR, homeobox transcript antisense RNA gene; siHotair, small interfering RNA targeting HOTAIR; siNC, small interfering RNA targeting negative control.

A

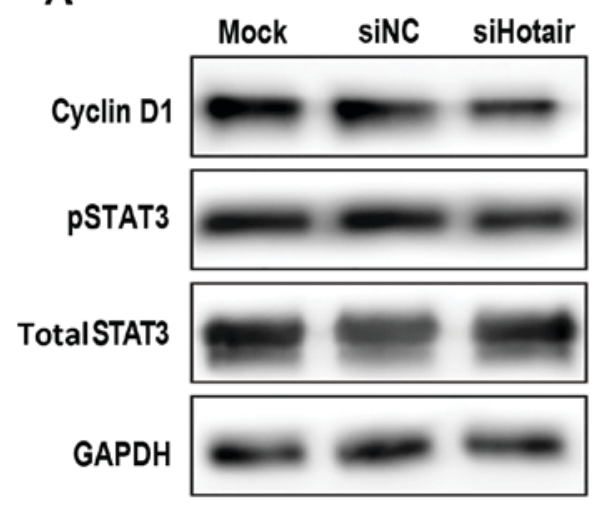

B

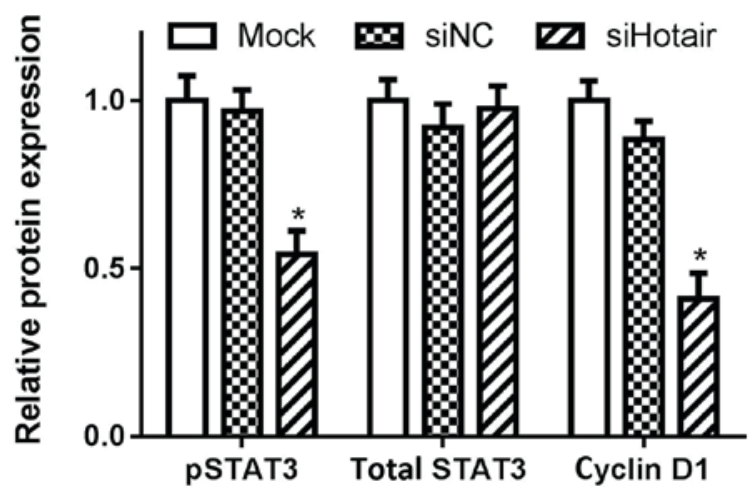

Figure 4. Knockdown of HOTAIR inhibits expression of cyclin D1 and pSTAT3 in Huh7 cells. Expression levels of pSTAT3, total STAT3 and cyclin D1 in Huh7 cells transfected with siHotair or siNC, or Mock transfected with Lipofectamine alone, as determined by (A) western blot analysis and (B) densitometric analysis. Data are presented as mean \pm standard deviation of three independent experiments. "P $<0.05$ vs. siNC. HOTAIR, homeobox transcript antisense RNA gene; siHotair, small interfering RNA targeting HOTAIR; siNC, small interfering RNA targeting negative control; STAT3, signal transducer and activator of transcription 3; pSTAT3, phosphorylated STAT3.

potential role of Hotair in promoting HCC development and progression and the regulation of proliferation and cell cycle progression, via cyclin D1 expression, and suggests that Hotair may be a potential therapeutic target for HCC treatment. In addition, Hotair has been reported to promote tumorigenesis, metastasis and drug resistance in multiple cancer types, 
A

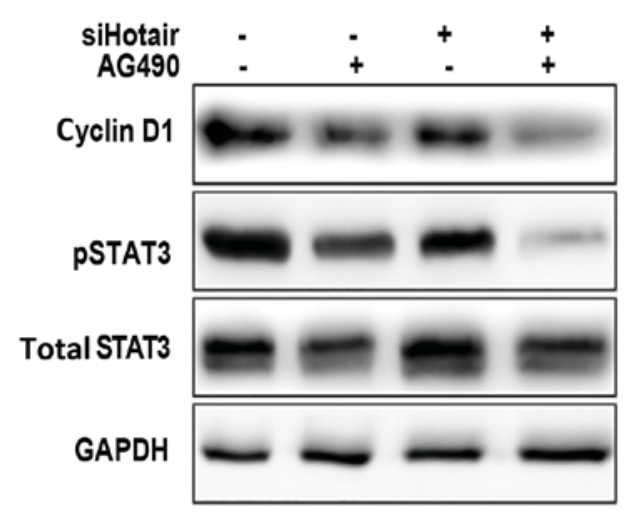

B

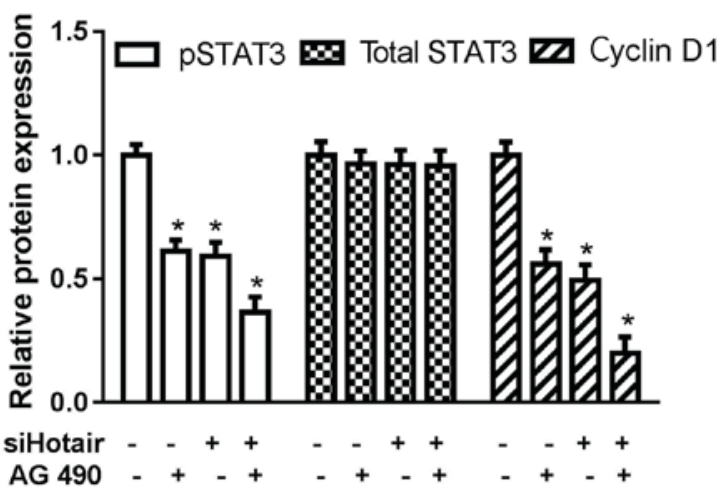

Figure 5. Knockdown of HOTAIR combined with STAT3 inhibition leads to an additional reduction in cyclin D1 expression. Huh7 cells were treated with the AG490 STAT3 inhibitor for $1 \mathrm{~h}$ prior to siHotair transfection, and the expression levels of pSTAT3, total STAT3 and cyclin D1 were detected by (A) western blot analysis and (B) densitometric analysis. Data are presented as mean \pm standard deviation of three independent experiments. ${ }^{*} \mathrm{P}<0.05$ vs. siHotair(-) AG490(-). HOTAIR, homeobox transcript antisense RNA gene; siHotair, small interfering RNA targeting HOTAIR; siNC, small interfering RNA targeting negative control; STAT3, signal transducer and activator of transcription 3; pSTAT, phosphorylated STAT3.

including $\mathrm{HCC}(3,8)$, suggesting that targeting Hotair as part of HCC treatment would be more beneficial than only direct inhibition of cyclin D1. However, further studies are required to confirm this.

The potential underlying molecular mechanism by which Hotair regulates cyclin D1 expression was investigated in the present study. $C C N D 1$ overexpression may occur due to constitutive activation of STAT3, a transcription factor that participates in cytokine signaling (20). It has been previously demonstrated that STAT3 is constitutively activated by phosphorylation of tyrosine residues in HCC and its activation may be associated with unlimited cell proliferation of cancer cells (20). In the present study, knockdown of HOTAIR inhibited STAT3 phosphorylation and reduced cyclin D1 expression. In addition, knockdown of HOTAIR combined with STAT3 inhibition led to an additional decrease in cyclin D1 expression, suggesting that STAT3 activation may have a mechanistic role in Hotair-mediated cyclin D1 expression and proliferation in HCC cells. Previous studies have demonstrated that Hotair interacts with the PRC2 complex, which is composed of subunits enhancer of zeste 2 polycomb repressive complex 2 subunit (EZH2), SUZ12 polycomb repressive complex 2 subunit and embryonic ectoderm development (EED) $(21,6)$. EZH2 binds to and methylates STAT3, leading to increased STAT3 activity by increasing tyrosine phosphorylation of STAT3. Inhibition of EZH2 reverses the silencing of Polycomb target genes and reduces STAT3 activity (22). Together with these studies, it was hypothesized in the present study, that lncRNA Hotair may activate STAT3 via EZH2/STAT3 signaling. Therefore, the data in the current study may partially explain the association between Hotair and CCNDI expression in HCC and also reveal the underlying mechanism of Hotair regulation of proliferation and cell cycle progression of HCC through activation of EZH2/STAT3/cyclin D1 signaling. In addition, Liu et al (23) demonstrated that STAT3 increased Hotair expression, suggesting that there may be a positive feedback loop between Hotair and STAT3, which may explain why a knockdown of HOTAIR combined with STAT3 inhibition led to additional decreases in cyclin D1 expression and STAT3 phosphorylation compared with individual treatments.

In addition, a previous study revealed a novel association between STAT3 activation and self-renewal modulation in cancer stem cells (CSCs) (24). STAT3-mediated Nanog expression was vital for liver CSCs in driving self-renewal and tumor initiation (23). Our previous study demonstrated that hepatitis $\mathrm{C}$ virus core regulated Nanog expression via activating STAT3 (25), and Hotair was expressed in CSCs and promoted malignant growth of liver CSCs (26). These findings suggested that activation of STAT3 by Hotair, may promote proliferation and cell cycle progression and modulate self-renewal of CSCs; therefore, Hotair may have a potential role in the modulation of the formation of CSCs and promoting HCC carcinogenesis and progression.

In conclusion, the present study revealed that Hotair was a novel regulator of the G1/S phase transition and proliferation in HCC cells by regulation of cyclin D1 expression and STAT3 singling. Despite the absence of an in vivo experiments and further studies that investigate whether Hotair regulates STAT3 activation via EZH2, the findings of the present study provide a novel insight into the mechanism of lncRNA-mediated hepatocarcinogenesis, and indicated that Hotair may be a promising therapeutic target for the inhibition of cell proliferation in $\mathrm{HCC}$.

\section{Acknowledgments}

The current study was supported by National Natural Science Foundation of China (grant no. 81000889), Natural Science Foundation of Guangdong Province, China (grant no.2016A030313218), Science and Technology Planning Project of Guangdong Province, China (grant no. 2014A020212094). This work was also supported by Grant (2013) 163 from Key Laboratory of Malignant Tumor Molecular Mechanism and Translational Medicine of Guangzhou Bureau of Science and Information Technology; grant no. KLB09001 from the Key Laboratory of Malignant Tumor Gene Regulation and Target Therapy of Guangdong Higher Education Institutes. 


\section{References}

1. Okuda K: Hepatocellular carcinoma. J Hepatol 32 (1 Suppl): S225-S237, 2000.

2. Mercer TR, Dinger ME and Mattick JS: Long non-coding RNAs: Insights into functions. Nat Rev Genet 10: 155-159, 2009.

3. Gupta RA, Shah N, Wang KC, Kim J, Horlings HM, Wong DJ, Tsai MC, Hung T, Argani P, Rinn JL, et al: Long non-coding RNA HOTAIR reprograms chromatin state to promote cancer metastasis. Nature 464: 1071-1076, 2010.

4. Rinn JL, Kertesz M, Wang JK, Squazzo SL, Xu X, Brugmann SA Goodnough LH, Helms JA, Farnham PJ, Segal E and Chang HY: Functional demarcation of active and silent chromatin domains in human HOX loci by noncoding RNAs. Cell 129: 1311-1323, 2007.

5. Kim K, Jutooru I, Chadalapaka G, Johnson G, Frank J, Burghardt R, Kim S and Safe S: HOTAIR is a negative prognostic factor and exhibits pro-oncogenic activity in pancreatic cancer. Oncogene 32: 1616-1625, 2013.

6. Kogo R, Shimamura T, Mimori K, Kawahara K, Imoto S, Sudo T, Tanaka F, Shibata K, Suzuki A, Komune S, et al: Long noncoding RNA HOTAIR regulates polycomb-dependent chromatin modification and is associated with poor prognosis in colorectal cancers. Cancer Res 71: 6320-6326, 2011.

7. Fang K, Liu P, Dong S, Guo Y, Cui X, Zhu X, Li X, Jiang L, Liu T and $\mathrm{Wu} Y$ : Magnetofection based on superparamagnetic iron oxide nanoparticle-mediated low lncRNA HOTAIR expression decreases the proliferation and invasion of glioma stem cells. Int J Oncol 49: 509-518, 2016.

8. Fu WM, Zhu X, Wang WM, Lu YF, Hu BG, Wang H, Liang WC, Wang SS, Ko CH, Waye MM, et al: Hotair mediates hepatocarcinogenesis through suppressing miRNA-218 expression and activating P14 and P16 signaling. J Hepatol 63: 886-895, 2015.

9. Gao JZ, Li J, DU JL and Li XL: Long non-coding RNA HOTAIR is a marker for hepatocellular carcinoma progression and tumor recurrence. Oncol Lett 11: 1791-1798, 2016.

10. Kato J, Matsushime H, Hiebert SW, Ewen ME and Sherr CJ: Direct binding of cyclin $\mathrm{D}$ to the retinoblastoma gene product $(\mathrm{pRb})$ and $\mathrm{pRb}$ phosphorylation by the cyclin $\mathrm{D}$-dependent kinase CDK4. Genes Dev 7: 331-342, 1993.

11. Leone G, DeGregori J, Jakoi L, Cook JG and Nevins JR: Collaborative role of E2F transcriptional activity and G1 cyclindependent kinase activity in the induction of $\mathrm{S}$ phase. Proc Natl Acad Sci USA 96: 6626-6631, 1999.

12. Hui AM, Makuuchi M and Li X: Cell cycle regulators and human hepatocarcinogenesis. Hepatogastroenterology 45: 1635-1642, 1998.

13. Sundarrajan M, Gupta S and Rao KV: Overexpression of cyclin D1 is associated with the decondensation of chromatin during den-induced sequential hepatocarcinogenesis. Cell Biol Int 26: 699-706, 2002.
14. Casimiro MC, Di Sante G, Ju X, Li Z, Chen K, Crosariol M, Yaman I, Gormley M, Meng H, Lisanti MP and Pestell RG: Cyclin D1 promotes androgen-dependent DNA damage repair in prostate cancer cells. Cancer Res 76: 329-338, 2016.

15. Jiang Y, Li Z, Zheng S, Chen H, Zhao X, Gao W, Bi Z, You K, Wang Y, Li W, et al: The long non-coding RNA HOTAIR affects the radiosensitivity of pancreatic ductal adenocarcinoma by regulating the expression of Wnt inhibitory factor 1 . Tumour Biol 37: 3957-3967, 2016.

16. Livak KJ and Schmittgen TD: Analysis of relative gene expression data using real-time quantitative PCR and the 2(-Delta Delta C(T)) method. Methods 25: 402-408, 2001.

17. Zhao F, Lin T, He W, Han J, Zhu D, Hu K, Li W, Zheng Z, Huang J and Xie W: Knockdown of a novel lincRNA AATBC suppresses proliferation and induces apoptosis in bladder cancer. Oncotarget 6: 1064-1078, 2015.

18. Zhou JJ, Meng Z, Zhou Y, Cheng D, Ye HL, Zhou QB, Deng XG and Chen RF: Hepatitis $\mathrm{C}$ virus core protein regulates OCT4 expression and promotes cell cycle progression in hepatocellular carcinoma. Oncol Rep 36: 582-588, 2016.

19. Hanahan D and Weinberg RA: Hallmarks of cancer: The next generation. Cell 144: 646-674, 2011.

20. He G and Karin M: NF- $\mathrm{KB}$ and STAT3-key players in liver inflammation and cancer. Cell Res 21: 159-168, 2011.

21. Tsai MC, Manor O, Wan Y, Mosammaparast N, Wang JK, Lan F, Shi Y, Segal E and Chang HY: Long noncoding RNA as modular scaffold of histone modification complexes. Science 329: 689-693, 2010

22. Kim E, Kim M, Woo DH, Shin Y, Shin J, Chang N, Oh YT, Kim H, Rheey J, Nakano I, et al: Phosphorylation of EZH2 activates STAT3 signaling via STAT3 methylation and promotes tumorigenicity of glioblastoma stem-like cells. Cancer Cell 23: 839-852, 2013

23. Liu Y, Luo F, Xu Y, Wang B, Zhao Y, Xu W, Shi L, Lu X and Liu Q: Epithelial-mesenchymal transition and cancer stem cells, mediated by a long non-coding RNA, HOTAIR, are involved in cell malignant transformation induced by cigarette smoke extract. Toxicol Appl Pharmacol 282: 9-19, 2015

24. Lee TK, Castilho A, Cheung VC, Tang KH, Ma S and Ng IO: $\mathrm{CD} 24(+)$ liver tumor-initiating cells drive self-renewal and tumor initiation through STAT3-mediated NANOG regulation. Cell Stem Cell 9: 50-63, 2011.

25. Zhou JJ, Chen RF, Deng XG, Zhou Y, Ye X, Yu M, Tang J, He XY, Cheng D, Zeng B, et al: Hepatitis $\mathrm{C}$ virus core protein regulates NANOG expression via the stat 3 pathway. FEBS Lett 588: 566-573, 2014.

26. Li H, An J, Wu M, Zheng Q, Gui X, Li T, Pu H and Lu D: LncRNA HOTAIR promotes human liver cancer stem cell malignant growth through downregulation of SETD2. Oncotarget 6: 27847-27864, 2015. 